Jahangirnagar University J. Biol. Sci. 4(1): 41-49, 2015 (June)

\title{
Anaesthetic efficacy of table salt on two live fishes Anabas testudineus and Channa punctatus
}

\author{
Selina Parween*, Md. Kamrul Ahsan ${ }^{1}$ and M. Manjurul Alam ${ }^{2}$ \\ Department of Zoology, University of Rajshahi, Rajshahi 6205, Bangladesh
}

\begin{abstract}
Different concentrations of table salt $(\mathrm{NaCl})$ were evaluated for its induction/anaesthetic and physiological effects on two live fish species viz., Anabas testudineus (Koi) and Channa punctatus (Taki). The time taken to immobilize and fully anaesthesize the fishes were quite long, 36-52.83 hours and 37.75-53 hours respectively for Koi, 64.50-71.50 hours and 68.2571.50 hours respectively for Taki, but thereafter a quick mortality occurred in both species. The induction time was negatively related with the concentrations of salt, and independent of the intrinsic factors (total length and total weight) of the fish. No changes in the colours of skin, eye and gill were observed at lower concentrations were observed in A. testudineus, but the eye and gill were found to be affected at low concentrations in C. punctatus, irrespective of the exposure time. Table salt produced a bad smell at all concentrations at longer exposure in both species of fish.
\end{abstract}

Key words: Sodium Chloride, induction, anaesthetic, A. testudineus, C. punctatus

\section{INTRODUCTION}

Fishes are subjected to stress everyday due to changes in the culture system, water quality, environment, and their physiology (Koeypudsa \& Jongjareanjai, 2011) and other stress factors regarding harvesting, handling and transportation (Woody et al., 2002). Stress disturbs the final internal balance of fish, such as behaviour, growth, reproduction, immune function and disease tolerance (Goos \& Consten, 2000; Tanck et al., 2000; Chen et al., 2004; Davis \& Griffin, 2004; Morales et al., 2005). To reduce the stress in fishes in culture system, in the research laboratory, handling and transportation several types of anaesthetics have been prescribed by the fisheries scientists. The scientists prefer low euthanization or sedation than full anaesthesia (Wurts, 1995; Davis \& Griffin, 2004). However, the degree of anaesthetization varies, for example, for therapeutic use, laboratory research and transportation comparatively longer induction time is preferable, otherwise, a recovery time within 15 minutes in clean water is desirable (Gilderhus \& Marking, 1987; Kaiser et al., 2006).

In this context a large number of anaesthetic compounds have been screened for use in aquaculture since a long time. The use of chemical fish anaesthetics sometimes showed

\footnotetext{
${ }^{1}$ Department of Zoology, New Government Degree College, Rajshahi, Rajshahi 6000, Bangladesh 2 Department of Fisheries, University of Rajshahi, Rajshahi 6205, Bangladesh

*Corresponding author. E-mail: selinaparween@yahoo.com
} 
hazardous effect in human and other animals when anaesthetized fish were subsequently eaten (Peake, 1998), and some of these compounds, an example, MS222 (tricaine methane sulphonate) is no longer used in some European countries (Kaiser et al., 2006), banned in Canada and restricted in United States (Peake, 1998). As an alternative to these chemical anaesthetics, food salts were introduced in aquaculture, research laboratories, and transportation of fishes and their fingerlings in live condition. Use of sodium bicarbonate was registered in USA as Low Regulatory Priority Compound (Peake, 1998; Bowser, 2001). Along with sodium chloride other food salts like sodium sulfate and sodium bicarbonate have been used to improve the quality of fish during transporting (Wurts, 1995; Gomes et al., 2006; Velasco-Santamaria \& Cruz-Casallas, 2008; Koeypudsa \& Jongjareanjai, 2011). The United States Food and Drug Administration (FDA) approved table salt or sodium chloride for use as anaesthetic on the food fish (Davis \& Griffin, 2004). The present research focused on the anaesthetic effect of table salt (sodium chloride) in two live fishes Anabas testudineus (Bloch) and Channa punctatus (Bloch).

\section{MATERIALS AND METHODS}

Selection of fish species: Both Anabas testudineus (Koi) and Channa punctatus (Taki) are hardy fish and can survive out of water for comparatively longer time hence they are marketed in live condition. These two species can live in any type of container with very small volume of water, and also can withstand a wide range of temperature. Both the fishes are popular for their taste. For these reasons they are selected for the present experiment to observe the anaesthetic effect of table salt and the effect on their morphology and behavior.

Collection of fish and acclimatization: Healthy A. testudineus and C. punctatus fishes were collected in live condition from the fish markets of Rajshahi city. After collection the fish were immediately placed in plastic buckets with water, and carried to the Fisheries laboratory of the Department of Zoology, University of Rajshahi.

In the laboratory the fishes were released in aerated aquaria. Two species were kept separately. Tap water was used in these aquaria. Five fishes were released in each aquarium containing 10 liter of water. For the first 24 hours no food was given to the fishes, and afterward rice bran and wheat flour in the form of small ball were given once daily. One third of water of the aquaria was removed daily and fresh water was added. The fishes were acclimatized for week. Feeding was withheld 24-h before the commencement of the experiments. Healthy fishes with strong physique were selected for the experiments.

Concentrations of salt used: A pilot experiment was run to find out the sublethal concentrations of salt on the test fishes. C. punctatus was found to be more susceptible to salt bath compared to A. testudineus. Based on the pilot experiment, two different sets of salt concentrations were chosen for the two species. The concentrations used against $A$. 
testudineus were $30,40,50$ and $60 \mathrm{mg}$ salt/l of water; and those were against $C$. punctatus were 5, 10, 15 and $20 \mathrm{mg}$ salt/l of water.

Experimentation: Experimental fishes were collected individually using a hand net to avoid any damage and released separate aquarium containing five liter of fresh tap water. Before releasing the fish the water was mixed with salt and stirred well with a glass rod. Thus three sets of aquaria were used for each concentration of salt, and each fish species. Control batches of both species were set similarly in untreated water. No food and aeration were allowed in the experimental aquaria. The experiments were conducted at room temperature $\left(17-20^{\circ} \mathrm{C}\right)$ for 80 hours.

The time was recorded when each fish was released in the experimental aquarium. The fishes were monitored continuously to observe the effect of salt. First induction to salt was determined as the stage where total loss of mobility became evident (immobilization) and full anaesthetization stage was that when the fish could no longer swim and/or maintain a vertical position in the water. The time taken for immobilization and induction (anaesthetization) of individual fish was recorded. To observe further effect of salt the fishes were kept in the treated water without running the recovery test. The time when death occurred was also recorded.

When the fishes became immobilized, total length (TL) and body weight (TW) of individual fish were measured carefully and quickly then released in the aquarium.

Changes in morphological characters and behavior: Similar sets of experiment were arranged with approximately similar size of fishes as mentioned, to observe the changes of some morphological characters and behavior of each species due to salt bath. Observations were made and the data recorded after 4-, 8-, 12- and 24 hours of exposure. The morphological characters studied included the colors of skin, eye, gills and smell. The swimming behavior of the fishes was observed.

Anaesthetic effect of salt on dissected fish (C. punctatus): Total 40 specimens of C. punctatus of different sizes (total length ranged from 145-160 mm) were immersed in a solution containing $200 \mathrm{~g}$ salt in a small quantity of water in a plastic bucket to induce the fish before and during dissection in a practical class. The observation is described in the result.

\section{RESULTS AND DISCUSSION}

Anaesthetic effect of salt: A. testudineus was found to be more resistant to the salt induction activity than $C$. punctatus. A concentrations of $40 \mathrm{mg} / \mathrm{l}$ salt immobilized $A$. testudineus at $52.83 \mathrm{~h}$, whereas, a concentrations of $30 \mathrm{mg} / \mathrm{l}$ did not affect the normal behavior of the fish up to 80-h of exposure. The fish became senseless after $53.00 \mathrm{~h}$ and died after $71.00 \mathrm{~h}$ at $40 \mathrm{mg} / \mathrm{l}$. At highest concentrations $(60 \mathrm{mg} / \mathrm{l})$ the time required to immobilize the fish at $36 \mathrm{~h}$; after $37.75 \mathrm{~h}$ the fish were fully induced and died after 40.50 h (Table 1a). 
Table 1a. Time (hour) required for inducing anaesthesia to Anabas testudineus by different concentrations of table salt

\begin{tabular}{c|c|c|c|c|c}
\hline $\begin{array}{c}\text { Concentrations } \\
\left(\mathrm{mgL}^{-1}\right)\end{array}$ & $\begin{array}{c}\text { Average total } \\
\text { length (mm) }\end{array}$ & $\begin{array}{c}\text { Average total } \\
\text { weight }(\mathrm{g})\end{array}$ & $\begin{array}{c}\text { Time for } \\
\text { immobilization }(\mathrm{h})\end{array}$ & $\begin{array}{c}\text { Time for } \\
\text { induction }(\mathrm{h})\end{array}$ & $\begin{array}{c}\text { Time for } \\
\text { total collapse } \\
(\mathrm{h})\end{array}$ \\
\hline 30 & 126.67 & 35.33 & - & - & - \\
40 & 120.00 & 31.67 & 52.83 & 53.00 & 71.00 \\
50 & 117.33 & 31.67 & 45.33 & 52.50 & 65.50 \\
60 & 114.00 & 31.83 & 36.00 & 37.75 & 40.50 \\
Control & 120.00 & 31.00 & - & - & - \\
\hline
\end{tabular}

In case of $C$. punctatus the lowest concentrations $(5 \mathrm{mg} / \mathrm{l})$ immobilized the fish at $71.50 \mathrm{~h}$, thereafter became slightly stressed, no lethal effect was observed after 80h exposure. At $10 \mathrm{mg} / \mathrm{l}$ the fish became immobilized after $67.50 \mathrm{~h}$, lost sense after $71.50 \mathrm{~h}$ and lived at a stressed condition up to the last of the experimental time. At highest concentrations (20 $\mathrm{mg} / \mathrm{l})$ the fish was motionless at $64.50 \mathrm{~h}$, fully induced at $68.25 \mathrm{~h}$ and died at $69.42 \mathrm{~h}$ (Table 1b).

Table 1b. Time (hour) required for inducing anaesthesia to Channa punctatus by different concentrations of table salt

\begin{tabular}{c|c|c|c|c|c}
\hline $\begin{array}{c}\text { Concent- } \\
\text { rations } \\
\left(\mathrm{mgL}^{-1}\right)\end{array}$ & $\begin{array}{c}\text { Average total } \\
\text { length }(\mathrm{mm})\end{array}$ & $\begin{array}{c}\text { Average total } \\
\text { weight }(\mathrm{g})\end{array}$ & $\begin{array}{c}\text { Time for } \\
\text { immobilization }(\mathrm{h})\end{array}$ & $\begin{array}{c}\text { Time for } \\
\text { induction (h) }\end{array}$ & $\begin{array}{c}\text { Time for total } \\
\text { collapse (h) }\end{array}$ \\
\hline 5 & 158.00 & 93.33 & 71.50 & - & - \\
10 & 151.67 & 38.00 & 67.50 & 71.50 & - \\
15 & 157.67 & 40.67 & 67.83 & 69.75 & 70.50 \\
20 & 153.67 & 38.67 & 64.50 & 68.25 & 69.42 \\
Control & 151.33 & 37.33 & - & - & - \\
\hline
\end{tabular}

In case of both the species, the time required for induction stages (motionless to death) were positively related with the extrinsic factor (concentrations of salt), but there was no relationship with the intrinsic factors (total length and total weight) of fish. The differences between induction time at different concentrations were insignificant (Tables $1 \mathrm{a}, \mathrm{b})$.

Observation on the dissected Channa punctatus: The fishes became induced within 1012 minutes in salt bath. To observe the internal organs the anaesthetized fishes were dissected open from thoracic to abdominal region (up to anus). It took nearly 30-40 minutes to complete the dissection. During this period it was noticed that heart of the dissected fishes were beating rhythmically but at a slight slow rate. Heart beat continued up to the end of the dissection class. Heart beat of these anaesthetized and dissected fishes were observed for $3.30 \mathrm{~h}$ (then the specimens were discarded). With all the trauma of incision, clearing some of the body muscles, pinning the abdominal muscles for clear view, the fishes were alive. 
Effect of salt on morphological and behavioral characters: Effect of salt on colors of skin, eye and gills and on the swimming behavior of both the species were studied at 4-, 8-, 12- and $24 \mathrm{~h}$ after treatment. The normal skin color (greenish-black) of A. testudineus remained unchanged at concentrations of 30 and $40 \mathrm{mg} / \mathrm{l}$ during the total exposure period; slight difference was observed at $40 \mathrm{mg} / \mathrm{l}$ after $24 \mathrm{~h}$. In concentrations of 50 and $60 \mathrm{mg} / \mathrm{l}$ the normal skin color was changed to brownish at12-h exposure. Later the color became light brown $(50 \mathrm{mg} / \mathrm{l}, 24 \mathrm{~h})$ and yellowish $(60 \mathrm{mg} / \mathrm{l}, 24-\mathrm{h})$ (Table $2 \mathrm{a})$. In $C$. punctatus white spots appeared on the skin at $12 \mathrm{~h}(5$ and $10 \mathrm{mg} / \mathrm{l})$ and $8 \mathrm{~h}(15$ and $20 \mathrm{mg} / \mathrm{l})$. The scales became loose after $24 \mathrm{~h}$ at 5 and $10 \mathrm{mg} / \mathrm{l}$, and $12 \mathrm{~h}$ at 15 and $20 \mathrm{mg} / \mathrm{l}$ (Table $2 \mathrm{~b}$ ).

Eye color of A. testudineus was quite normal (transparent) throughout 24h exposure at 30 and $40 \mathrm{mg} / \mathrm{l}$, which changed to brownish after 12 to $24 \mathrm{~h}(50 \mathrm{mg} / \mathrm{l}), 8$ to $12 \mathrm{~h}(60 \mathrm{mg} / \mathrm{l})$ and then yellowish at $24 \mathrm{~h}$ at $60 \mathrm{mg} / \mathrm{l}$ (Table 2a). Eye color of C. punctatus was affected more at lower concentrations compared to A. testudineus. After $12 \mathrm{~h}$ eye became yellowish (5 and $10 \mathrm{mg} / \mathrm{l})$. Then the color became cloudy after $24 \mathrm{~h}(5 \mathrm{mg} / \mathrm{l})$ and whitish $(10 \mathrm{mg} / \mathrm{l})$. After $8 \mathrm{~h}$ the eye became cloudy in the fishes kept in 15 and $20 \mathrm{mg} / \mathrm{l}$ of salt (Table 2b).

Table 2a. Effect of table salt on morphological characters and behavior of Anabas testudineus at different exposure time (hour)

\begin{tabular}{|c|c|c|c|c|c|c|}
\hline \multirow{2}{*}{$\begin{array}{c}\text { Concent } \\
\text { rations } \\
\left(\mathrm{mgL}^{-1}\right)\end{array}$} & \multirow{2}{*}{$\begin{array}{l}\text { Exposure } \\
\text { time (h) }\end{array}$} & \multicolumn{5}{|c|}{ Parameters } \\
\hline & & Skin colour & Eye colour & Gill colour & Smell & Movement \\
\hline 00 & 24 & $\begin{array}{l}\text { Normal } \\
\text { (greenish } \\
\text { black) }\end{array}$ & $\begin{array}{c}\text { Normal } \\
\text { (transparen } \\
\text { t/clear) }\end{array}$ & Deep Red & Normal & Normal (frequent) \\
\hline \multirow{4}{*}{30} & 4 & Normal & Normal & Deep Red & Normal & Normal \\
\hline & 8 & Normal & Normal & Red & Normal & Rapid \\
\hline & 12 & Normal & Normal & Red & Fishy & Slightly slow \\
\hline & 24 & Normal & Normal & Pale Red & Fishy & Slow \\
\hline \multirow{4}{*}{40} & 4 & Normal & Normal & Red & Normal & Stressing \\
\hline & 8 & Normal & Normal & Red & Normal & Stressing \\
\hline & 12 & Normal & Normal & Red & Fishy & Slow \\
\hline & 24 & Light Green & Normal & Pale Red & Fishy & Slow \\
\hline \multirow{4}{*}{50} & 4 & Normal & Normal & Red & Normal & Rapid \\
\hline & 8 & Normal & Normal & Red & Fishy & Striving \\
\hline & 12 & Brownish & Brownish & Pale Red & Fishy & Slow \\
\hline & 24 & Light Brown & Brownish & Brownish & Fishy & Very slow \\
\hline \multirow{4}{*}{60} & 4 & Normal & Normal & Pale Red & Normal & Stressing \\
\hline & 8 & Normal & Brownish & Pale Red & Fishy & Stressing \\
\hline & 12 & Brownish & Brownish & Brownish & Fishy & Slow \\
\hline & 24 & Yellowish & Yellowish & Yellowish & Fishy & Very slow \\
\hline
\end{tabular}

The normal gill color (deep red) was changed to reddish (8-12 h), pale red (24 h) at 30 $\mathrm{mg} / \mathrm{l}$; red (4 to $12 \mathrm{~h})$, pale red $(24 \mathrm{~h})$ at $40 \mathrm{mg} / \mathrm{l}$; red $(4$ to $8 \mathrm{~h})$, pale red $(12 \mathrm{~h})$, brownish $(24 \mathrm{~h})$ at $50 \mathrm{mg} / \mathrm{l}$; pale red $(4$ to $8 \mathrm{~h})$, brownish $(12 \mathrm{~h})$, yellowish $(24 \mathrm{~h})$ at $60 \mathrm{mg} / \mathrm{l}$ in $A$. 
testudineus (Table 2a). Gill color of $C$. punctatus was changed after $8 \mathrm{~h}$ in $5 \mathrm{mg} / \mathrm{l}$ and after $4 \mathrm{~h}$ at other higher concentrations (Table 2b).

Fishy smell appeared at all concentrations levels after 8 to $12 \mathrm{~h}$ in both the species. The smell was more intensed in $C$. punctatus at all concentrations and exposure times (Tables $2 \mathrm{a}, \mathrm{b})$. The odd smell was increased with the concentrations and exposure time.

Table 2b. Effect of table salt on morphological characters and behavior of Channa punctatus at different exposure time (hour)

\begin{tabular}{|c|c|c|c|c|c|c|}
\hline \multirow{2}{*}{$\begin{array}{l}\text { Concent } \\
\text { rations } \\
\left(\mathrm{mgL}^{-1}\right)\end{array}$} & \multirow{2}{*}{$\begin{array}{c}\text { Exposure } \\
\text { time }(\mathrm{h})\end{array}$} & \multicolumn{5}{|c|}{ Parameters } \\
\hline & & Skin colour & Eye colour & Gill colour & Smell & Movement \\
\hline \multirow[t]{2}{*}{00} & 24 & $\begin{array}{c}\text { Normal } \\
\text { (yellowish } \\
\text { black) }\end{array}$ & $\begin{array}{c}\text { Normal } \\
\text { (transparent/ } \\
\text { clear) }\end{array}$ & Deep Red & Normal & $\begin{array}{c}\text { Normal } \\
\text { (frequent) }\end{array}$ \\
\hline & 4 & Normal & Normal & Deep Red & Normal & Slow \\
\hline \multirow{3}{*}{5} & 8 & Normal & Normal & Reddish & Normal & Slow \\
\hline & 12 & White spots & Yellowish & Pale Red & Fishy & Slow \\
\hline & 24 & Loose scales & Cloudy & Brownish & Fishy & $\begin{array}{c}\text { Rapid, } \\
\text { unbalanced }\end{array}$ \\
\hline \multirow{4}{*}{10} & 4 & Normal & Normal & Reddish & Normal & Rapid \\
\hline & 8 & Normal & Normal & Pale Red & Normal & Slow \\
\hline & 12 & White spots & Yellowish & Brownish & Fishy & Slow \\
\hline & 24 & Loose scales & Whitish & Brownish & Fishy & Very slow \\
\hline \multirow{4}{*}{15} & 4 & Normal & Normal & Reddish & Normal & Rapid \\
\hline & 8 & White spots & Cloudy & Brownish & Fishy & Striving \\
\hline & 12 & Loose scales & Cloudy & Brownish & Fishy & Slow \\
\hline & 24 & Grayish & Cloudy & Yellowish & Fishy & Very slow \\
\hline \multirow{4}{*}{20} & 4 & Normal & Normal & Reddish & Normal & Stressing \\
\hline & 8 & $\begin{array}{c}\text { White or black } \\
\text { spots }\end{array}$ & Cloudy & Brownish & Fishy & Slow \\
\hline & 12 & Loose scales & Cloudy & Yellowish & Fishy & Slow \\
\hline & 24 & Whitish & Cloudy & Pale yellow & Fishy & Very slow \\
\hline
\end{tabular}

Salt bath affected the normal swimming movement of both the fishes at all concentrations levels throughout the experimental period. C. punctatus showed more stressed behavior (swimming and opercular rate). A. testudineus showed rapid swimming at $4 \mathrm{~h}$ exposure and then moved slowly ( 8 to $24 \mathrm{~h})$ at $30 \mathrm{mg} / \mathrm{l}$; slow $(4 \mathrm{~h})$ then stressed and finally very slow movements at $40 \mathrm{mg} / \mathrm{l}$. At $50 \mathrm{mg} / \mathrm{l}$ the fishes rapidly swam $(4 \mathrm{~h})$, began to strive $(8$ h) and then swam slowly. Stressed movement was noticed at $60 \mathrm{mg} / \mathrm{l}$ at $4 \mathrm{~h}$ and then swimming became slow from $12 \mathrm{~h}$ onward (Table 2a). Movement became slow during 4 to $12 \mathrm{~h}$ and then rapid and unbalanced swimming was noticed in C. punctatus at $5 \mathrm{mg} / \mathrm{l}$. At $10 \mathrm{mg} / \mathrm{l}$ the fish swam rapidly during first $4 \mathrm{~h}$ then it became slow gradually. Rapid swimming was noticed at $4 \mathrm{~h}$ then the fish strived $(8 \mathrm{~h})$ and became slow from $12 \mathrm{~h}$ at 15 $\mathrm{mg} / \mathrm{l}$. At $20 \mathrm{mg} / \mathrm{l}$ the fish showed stressed movement from more or less half an hour and 
then gradually became slow (Table $2 \mathrm{~b}$ ). C. punctatus tried to escape from the salt treated water after $1-2 \mathrm{~h}$ at concentrations of $10-20 \mathrm{mg} / \mathrm{l}$.

Table salt or sodium chloride is one of the most commonly used drugs in the aquaculture, and fisheries scientists referred it as the 'aspirin of aquaculture' (Swann \& Fitzgerald, 1992), as it is a therapeutic against the bacterial diseases in fish (Van Duijn, 1973) and also to treat the ectoparasites of fish, like Costia, Epistylis, Trichodina, Chilodonella, Dactylogyrus and Gyrodactylus (Swann \& Fitzgerald, 1992). Fashina-Bombata \& Busari (2003) reported that salt treatment is potential to control pathogens in developmental stages of African catfish.

During transportation of live fish a higher percentage of mortality occurs due to the activation of latent disease organisms and osmoregulatory problem (Jensen, 1990) and addition of sodium chloride is able to minimize these stresses (Francis-Floyd, 1995). During the transportation of live juvenile fish in tropical countries bacterial proliferation occurs, which can be prevented by adding either sodium chloride or methylene blue in the transporting water (Fajardo, 2002).

The anaesthetic effect of table salt was observed on two hardy fishes, A. testudineus and C. punctatus, and found that Anabas can tolerate comparatively higher concentrations of salt than Channa; but the induction time was less in Anabas than that of Channa. Anabas was induced in between 37-53 h, and Channa was induced in between 68-72h, depending on the concentrations. The long time taken for induction could be enhanced by using higher concentrations than those were used in this experiment. Toxicity of salt based on induction time was found to be dependent on the concentration of salt, but not with the total length or total weight of the fishes. The survival time for mosquito fish in salt bath was found to be correlated with the extrinsic factor like salt concentration and intrinsic factor like total weight (Newman \& Aplin, 1992).

It was noticed that after total induction both the species died quickly. That means the concentrations used affected the salt level of blood and created osmotic imbalance. Wurts (1995) reported that $10 \%$ dehydration occurs in live fish when $10 \mathrm{~g} / \mathrm{l}$ salt was added to the transported water, and resulted in lethality. The author also reported that salt tolerance varies among different species and the temperature.

Both the species suffered salt stress at an exposure of $72 \mathrm{~h}$ at all concentrations levels. Channa was more stressed than Anabas. The color of skin, eye and gills were affected at higher concentrations and longer exposure in Anabas. At all concentrations levels from 5$20 \mathrm{mg} / \mathrm{l}$, skin color changed loosing the brightness and slime secretion was enhanced in $C$. punctatus, and at longer exposure the scales became loose. The eye color became dull and cloudy and the gills lost the normal deep red color. Salt affected the eye at exposure more than 10h. Normal blood circulation in the gills was affected severely and respiratory stress was detected by discolored gills and rapid opercular rate, along with abnormal and unbalanced slow swimming. However, $C$. punctatus was alive in anaesthetized condition and tolerated the stress of dissecting trauma for more than three hours. 
Besides handling and transportation, other stress factors like chill coma in tropical fish (Sun et al., 1995), physical damage and high nitrate level (Andrews et al., 2002) can also be prevented by the application of salt. Authors also reported the threat of osmoregulatory and other physiological stress occurred due to higher concentration of salt (Andrews et al., 2002; Burgdorf-Moisuk et al., 2011). Again it is observed that the anaesthetic stress in fish can be lowered if sodium chloride is applied along with the anaesthetic (Davis \& Griffin, 2004).

Table salt was found to be a good anaesthetic agent which affect the heart rate insignificantly in $C$. punctatus for more than 3-h in severe traumatic stage and keep the fish alive. The salt concentrations used in the present experiment did not induce both the species quickly, but higher concentrations would be acted as quick inducing agent. Longer exposure to the salt at higher concentrations than the salt content in the fish blood would be fatal, so it is better to use salt in transporting water for juveniles and live fishes and also as therapeutic purpose in pisciculture, rather to use as an anaesthetic.

\section{REFERENCES}

Andrews, C., Exell, A. and Carrington, N. 2002. The Interpet Manual of Fish Health (A. Exell ed.). Interpet Publishing, Surrey, UK. pp. 193-195.

Bowser, P.R. 2001. Anesthetic options for fish. In: Recent Advances in Veterinary Anesthesia and Analgesia: Companion Animals (R.D. Gleed and J.W. Ludders eds.). International Veterinary Information Service, Ithaca NY (www.ivis.org; A1412.0701).

Burgdorf-Moisuk, A., Mitchell, M.A. and Watson, M. 2011. Clinical and physiologic effects of sodium chloride baths in goldfish (Carassius auratus). Journal of Zoo and Wildlife Medicine, 42(4): 586-592.

Chen, C., Wooster, G.A. and Bowser, P.R. 2004. Comparative blood chemistry and histopathology of tilapia infected with Vibrio vulnificus or Streptococcus iniae or exposed to carbon tetrachloride, gentamicin, or copper sulfate. Aquaculture, 239: 421-443.

Davis, K.B. and Griffin, B.R. 2004. Physiological responses of hybrid striped bass under sedation by several anesthetics. Aquaculture, 233(1-4): 531-548.

Fashina-Bombata, H.A. and Busari, A.N. 2003. Influence of salinity on the developmental stages of African catfish Heterobranchus longifilis (Valenciennes, 1840). Aquaculture, 224(1-4): 213-222.

Fajardo, L.J. 2002. Effect of zeolitic material on ammonia concentration during fish transport. Undergraduate Thesis, College of Fisheries, Central Luzon State University, Science City of Muñoz, Nueva Ecija, 55 pp.

Francis-Floyd, R. 1995. The use of salt in aquaculture. Fact Sheet VM 86, Institute of Food and Agricultural Sciences, Cooperative Extension Service, University of Florida, 3pp. http://edis.ifas.ufl.edu/BODY-VM007.

Gilderhus, P.A. and Marking, L.L. 1987. Comparative efficacy of 16 anesthetic chemicals on rainbow trout. North American Journal of Fisheries Management, 7: 288-292.

Gomes, L.C., Chagas, E.C., Brinn, R.P., Roubach, R., Coppati, C.E. and Baldisserotto, B. 2006. Use of salt during transportation of air breathing pirarucu juveniles (Arapaima gigas) in plastic bags. Aquaculture, 256: 521-528. 
Goos, H.J.T. and Consten, D. 2002. Stress adaptation, cortisol and pubertal development in the male common carp, Cyprinus carpio. Molecular and Cellular Endocrinology, 197(1-2): 105-116.

Jensen, G.L. 1990. Transportation of Warmwater Fish: Equipment and Guidelines. SRAC Publication No. 390, 4pp.

Kaiser, H., Brill, G., Cahill, J., Collett, P., Czypionka, K., Green, A., Orr, K., Pattrick, P., Scheepers, R., Stonier, T., Whitehead, M.A. and Yearsley, R. 2006. Testing clove oil as an anaesthetic for long-distance transport of live fish: the case of the Lake Victoria cichlid Haplochromis obliquidens. Journal of Applied Ichthyology, 22: 510-514.

Koeypudsa, W. and Jongjareanjai, M. 2011. Impact of water temperature and sodium chloride $(\mathrm{NaCl})$ on stress indicators of hybrid catfish (Clarias garieppinus Burcell $\times$ C. macrocephalus Gunther). Songklanakarin Journal of Science and Technology, 33(4): 369-378.

Morales, A.E., Cardenete, G., Abellan, E. and Garcia-Rejon, L. 2005. Stress-related physiological responses to handling in common dentex (Dentex dentex Linnaeus, 1758). Aquaculture Research, 36: 33-40.

Newman, M.C. and Aplin, M.S. 1992. Enhancing toxicity data interpretation and prediction of ecological risk with survival time modeling: an illustration using sodium chloride toxicity to mosquitofish (Gambusia holbrooki). Aquatic Toxicology, 23(2): 85-96.

Peake, S. 1998. Sodium Bicarbonate and Clove oil as Potential Anesthetics for Nonsalmonid Fishes. North American Journal of Fisheries Management, 18(4): 919-924.

Sun, L., Chen, G. and Chang, C. 1995. Acute responses of blood parameters and comatose effects in salt-acclimated tilapias exposed to low temperatures. Journal of Thermal Biology, 20(3): 299-306.

Swann, L. and Fitzgerald, S. 1992. Use and application of salt in aquaculture. Aquaculture extension fact sheet $A S-458$, Ilinois- Indiana Sea Grant Program, 2 pp.

Tanck, M.W.T., Booms, G.H.R., Eding, E.H., Wendelaar Bonga, S.E. and Komen, J. 2000. Cold shocks: a stressor for common carp. Journal of Fish Biology, 57: 881-894.

van Duijn, C. Jr. 1973. Diseases of Fishes, $3^{\text {rd }}$ edn. Butterworth and Co. Ltd., London, 372pp.

Velasco-Santamaria, Y.M. and Cruz-Casallas, P.E. 2008. Behavioural and gill histopathological effects of acute exposure to sodium chloride in moneda (Metynnis orinocensis). Environmental Toxicology and Pharmacology, 25(3): 365-372.

Woody, C.A., Nelson, J. and Ramstad, K. 2002. Clove oil as an anaesthetic for adult sockeye salmon: field trials. Journal of Fish Biology, 60(2): 340-347.

Wurts, W.A. 1995. Using salt to reduce handling stress in channel catfish. World Aquaculture, 26(3): 80-81. 